\title{
Post-intervention Status in Patients With Refractory Myasthenia Gravis Treated With Eculizumab During REGAIN and Its Open-Label Extension
}

Renato Mantegazza, MD, Gil I. Wolfe, MD, Srikanth Muppidi, MD, Heinz Wiendl, MD, Kenji P. Fujita, MD, Fanny L. O'Brien, PhD, Heather D.E. Booth, DPhil, and James F. Howard, Jr., MD, on behalf of the REGAIN Study Group

Neurology ${ }^{\circledR}$ 2021;96:e610-e618. doi:10.1212/WNL.0000000000011207

\section{Abstract}

\section{Objective}

To evaluate whether eculizumab helps patients with anti-acetylcholine receptor-positive (AChR+) refractory generalized myasthenia gravis (gMG) achieve the Myasthenia Gravis Foundation of America (MGFA) post-intervention status of minimal manifestations (MM), we assessed patients' status throughout REGAIN (Safety and Efficacy of Eculizumab in AChR+ Refractory Generalized Myasthenia Gravis) and its open-label extension.

\section{Methods}

Patients who completed the REGAIN randomized controlled trial and continued into the open-label extension were included in this tertiary endpoint analysis. Patients were assessed for the MGFA postintervention status of improved, unchanged, worse, MM, and pharmacologic remission at defined time points during REGAIN and through week 130 of the open-label study.

\section{Results}

A total of 117 patients completed REGAIN and continued into the open-label study (eculizumab/ eculizumab: 56; placebo/eculizumab: 61). At week 26 of REGAIN, more eculizumab-treated patients than placebo-treated patients achieved a status of improved ( $60.7 \%$ vs $41.7 \%)$ or MM (25.0\% vs $13.3 \%$; common OR: 2.3 ; 95\% CI: 1.1-4.5). After 130 weeks of eculizumab treatment, $88.0 \%$ of patients achieved improved status and $57.3 \%$ of patients achieved MM status. The safety profile of eculizumab was consistent with its known profile and no new safety signals were detected.

\section{Conclusion}

Eculizumab led to rapid and sustained achievement of MM in patients with AChR+ refractory gMG. These findings support the use of eculizumab in this previously difficult-to-treat patient population.

\section{ClinicalTrials.gov Identifier}

REGAIN, NCT01997229; REGAIN open-label extension, NCT02301624.

\section{Classification of Evidence}

This study provides Class II evidence that, after 26 weeks of eculizumab treatment, $25.0 \%$ of adults with $\mathrm{AChR}+$ refractory gMG achieved MM, compared with $13.3 \%$ who received placebo.

\author{
Correspondence \\ Dr. Howard \\ howardj@neurology.unc.edu
}

MORE ONLINE

$\rightarrow$ Class of Evidence

Criteria for rating

therapeutic and diagnostic studies

NPub.org/coe 


\section{Glossary}

AChR+ = anti-acetylcholine receptor-positive; $\mathbf{C I}=$ confidence interval; gMG = generalized myasthenia gravis; IST = immunosuppressive therapy; $\mathbf{M G}=$ myasthenia gravis; MG-ADL = Myasthenia Gravis Activities of Daily Living; MGFA = Myasthenia Gravis Foundation of America; $\mathbf{M M}=$ minimal manifestations; $\mathbf{O R}=$ odds ratio; PR = pharmacologic remission; REGAIN = Safety and Efficacy of Eculizumab in AChR+ Refractory Generalized Myasthenia Gravis.

In most patients with myasthenia gravis (MG), the disease is managed using immunosuppressive therapies (ISTs); however, $10 \%-15 \%$ of patients do not respond adequately to ISTs, experience intolerable adverse events, or require maintenance IV immunoglobulin or plasma exchange treatment. ${ }^{1-3}$ These patients are considered to have refractory $\mathrm{MG}$, which can severely affect their health-related quality of life and increase the socioeconomic burden of the disease. ${ }^{4}$

There is a consensus that the treatment goal for patients with generalized MG (gMG) should be achievement of a Myasthenia Gravis Foundation of America (MGFA) postintervention status of minimal manifestations (MM), defined as having no symptoms indicating functional limitations, or better. ${ }^{3,5,6}$

Eculizumab (Soliris, Alexion Pharmaceuticals, Boston, MA) is a humanized monoclonal antibody that specifically binds and inhibits cleavage of human terminal complement protein $\mathrm{C} 5$. $^{7}$ The 6-month, phase 3, randomized, placebo-controlled REGAIN study (Safety and Efficacy of Eculizumab in Antiacetylcholine Receptor-Positive $[\mathrm{AChR}+]$ Refractory Generalized Myasthenia Gravis) demonstrated the efficacy and safety of eculizumab in patients with AChR+ refractory gMG. ${ }^{8}$ An interim analysis of the REGAIN open-label extension results found that eculizumab's benefits for this population were maintained through 3 years of treatment. ${ }^{9}$ MGFA postintervention status was assessed as a tertiary endpoint in these studies. At the date of the open-label study interim analysis, $74.1 \%$ of patients had an MGFA post-intervention status of improved, and $56.0 \%$ were considered to have achieved MM or pharmacologic remission (PR). ${ }^{9}$ We report a detailed evaluation of final data from the open-label study on patients' response to eculizumab treatment during REGAIN and up to open-label week 130 using MGFA post-intervention status.

\section{Methods}

\section{Standard Protocol Approvals, Registrations, and Patient Consents}

All patients provided written, informed consent. Independent ethics committees or institutional review boards provided written approval for the study protocols and all amendments. The studies were performed in accordance with the ethical standards laid down in the 1964 Declaration of Helsinki and are registered with clinicaltrials.gov (identifiers: for REGAIN, NCT01997229; for the REGAIN open-label extension, NCT02301624).

\section{Study Design and Participants}

REGAIN was a 6-month, phase 3, randomized, placebocontrolled study of eculizumab in patients aged 18 years or older with AChR+ refractory gMG. ${ }^{8}$ Patients who completed REGAIN were eligible for inclusion in the open-label study and were required to enroll within 2 weeks of completing REGAIN. ${ }^{9}$ Patients were eligible for inclusion in REGAIN if they had confirmed gMG, AChR+ serology, and a Myasthenia Gravis Activities of Daily Living (MG-ADL) total score of at least 6 , and had received 2 or more ISTs, or at least 1 IST with IV immunoglobulin or plasma exchange treatment at least 4 times in 12 months without symptom control. Patients with ocular MG (MGFA Class I) or myasthenic crisis at screening (MGFA Class V) were excluded from the trial. Full eligibility criteria have been published previously. ${ }^{8}$ All participants were required to have been vaccinated against Neisseria meningitidis at least 2 weeks before starting study treatment; individuals who were not vaccinated at the appropriate time received prophylactic antibiotics until 2 weeks after vaccination. During the open-label study, patients were revaccinated according to local guidelines in the country where they were treated, all of which recommended revaccination after 2-5 years to maintain active coverage. During REGAIN, patients who previously received ISTs were required to maintain their prestudy dose and schedule. During the open-label study, modifications to IST dose and schedule were permitted at the discretion of the investigator; however, changes were not required by the protocol.

\section{Dosing of Eculizumab}

In REGAIN, patients randomized to receive eculizumab were given an induction dose of $900 \mathrm{mg}$ on day 1 and at weeks 1,2 , and 3, followed by a maintenance dose of $1,200 \mathrm{mg}$ at week 4 and every 2 weeks thereafter (figure 1$)^{8}$ Placebo was administered on the same schedule. Patients who received eculizumab during REGAIN continued to receive it during the open-label study (eculizumab/eculizumab arm) and those who received placebo during REGAIN started eculizumab treatment upon entering the open-label study (placebo/ eculizumab arm). ${ }^{9}$ To preserve the blinded nature of REGAIN, patients who continued into the open-label study underwent a 4-week blinded induction phase (figure 1). During this phase, patients in the eculizumab/eculizumab group received eculizumab $1,200 \mathrm{mg}$ on day 1 and at week 2 , and placebo at weeks 1 and 3. Patients in the placebo/ eculizumab group received eculizumab $900 \mathrm{mg}$ on day 1 and at weeks 1, 2, and 3. All patients were then given open-label eculizumab 1,200 $\mathrm{mg}$ at week 4 and every 2 weeks thereafter 

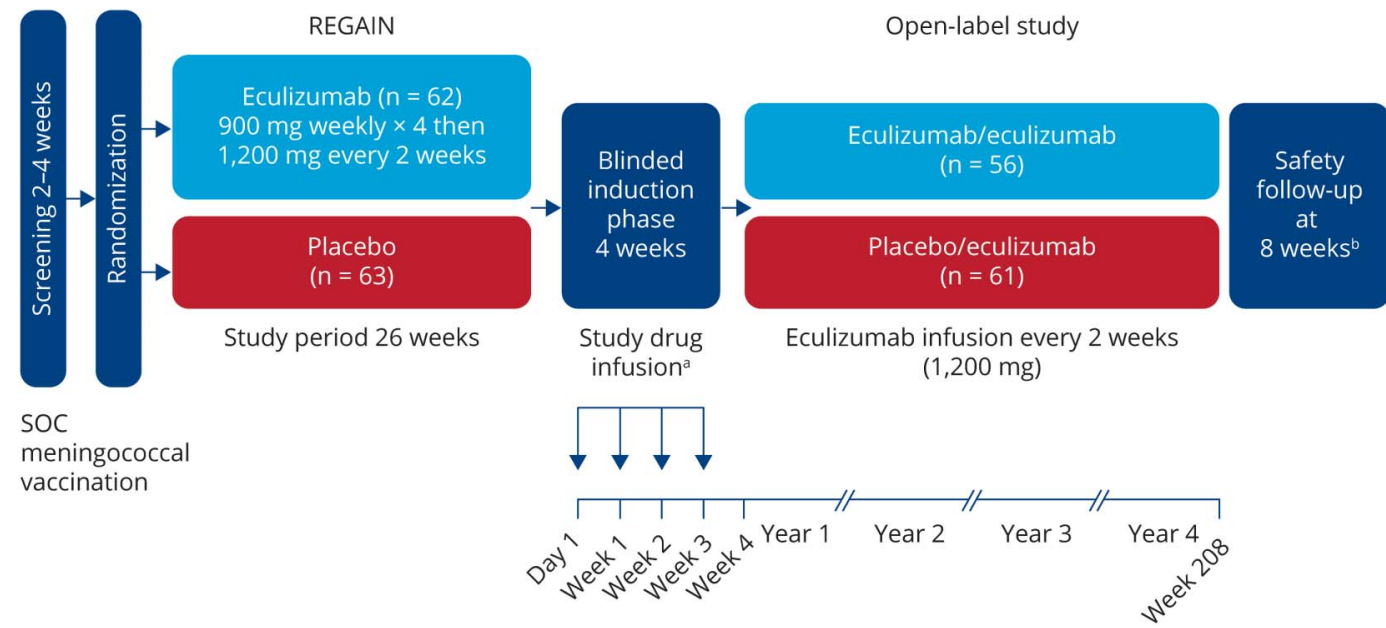

${ }^{a}$ During the blinded induction phase of the open-label study, patients received eculizumab (1,200 mg; 4 vials) on day 1 and at week 2 and placebo ( 4 vials) at weeks 1 and 3 (eculizumab/eculizumab group), or placebo (1 vial) plus eculizumab (900 mg; 3 vials) each week (placebo/eculizumab group). ${ }^{\text {b }}$ Patients who withdrew from or discontinued participation in the study after receiving any amount of eculizumab were required to complete a safety follow-up visit 8 weeks after their last eculizumab dose. REGAIN = Safety and Efficacy of Eculizumab in Anti-acetylcholine Receptor-Positive Refractory Generalized Myasthenia Gravis; SOC = standard of care. Figure reproduced with permission (creativecommons.org/licenses/by-nc/4.0/) from Muppidi et al. ${ }^{9}$

until it was otherwise available to them, for up to a maximum of 4 years. The extension study was completed with final database lock in January 2019.

\section{Assessments}

The objectives of REGAIN and the open-label study were to assess the efficacy of eculizumab, as measured by change in MG-ADL total score from baseline, and to evaluate its safety. This analysis assessed the tertiary endpoint of MGFA postintervention status and safety data during REGAIN and the open-label study for patients who continued into the openlabel study.

MGFA post-intervention status can be used to evaluate changes in a patient's condition following treatment, including improvement, worsening, or no change of clinical manifestations from pretreatment. ${ }^{6}$ MGFA post-intervention status following administration of eculizumab or placebo during REGAIN, including achievement of MM, was assessed at weeks 4, 12, and 26 of REGAIN and weeks 26, 40, 52, 78, 104 , and 130 of the open-label study and was based on comparison with patients' disease state before REGAIN. MGFA post-intervention status was reported as improved if a patient's pretreatment clinical manifestations were substantially decreased, worse if they were substantially increased, or unchanged if they were not substantially changed compared with REGAIN baseline. In this analysis, the group of patients with improved status included patients who achieved MM or PR. In patients with improved status, MM was achieved if they had no symptoms indicating functional limitations from MG but had some weakness on examination of some muscles. ${ }^{6}$ Subcategories of MM relating to treatment status were not assessed. Patients were evaluated for PR at open-label study weeks $26,40,52,78,104$, and 130 . PR was achieved if patients had no signs or symptoms of MG for at least 1 year and, upon examination, had no weakness of any muscle, other than isolated weakness of eyelid closure.

Daily doses of corticosteroids, azathioprine, and mycophenolate mofetil were recorded throughout the open-label study.

Adverse events were recorded and coded by preferred term using the Medical Dictionary for Regulatory Activities Version 20.1. MG exacerbations, use of rescue therapy, and study discontinuations because of adverse events were also recorded.

\section{Statistical Analysis}

Patients who were not assessed for MGFA post-intervention status at a particular time point were not included in the analysis for that time point.

The common odds ratio (OR) and the associated 95\% confidence intervals (CIs) for achievement of improved status or MM at REGAIN week 26 for patients who received eculizumab compared with those who received placebo were calculated using an ordinal logistic regression model with MGFA post-intervention status (achieved MM, improved but MM not achieved, unchanged, or worse) as a dependent variable, and treatment group as an independent variable.

For between-group comparisons, 95\% CIs of the differences in means were based on the $t$-distribution for continuous variables. Within a single treatment group, 95\% CIs were calculated using the Clopper-Pearson method. 
Figure 2 Patient Disposition in REGAIN (Safety and Efficacy of Eculizumab in Anti-acetylcholine Receptor-Positive Refractory Generalized Myasthenia Gravis) and the Open-Label Study

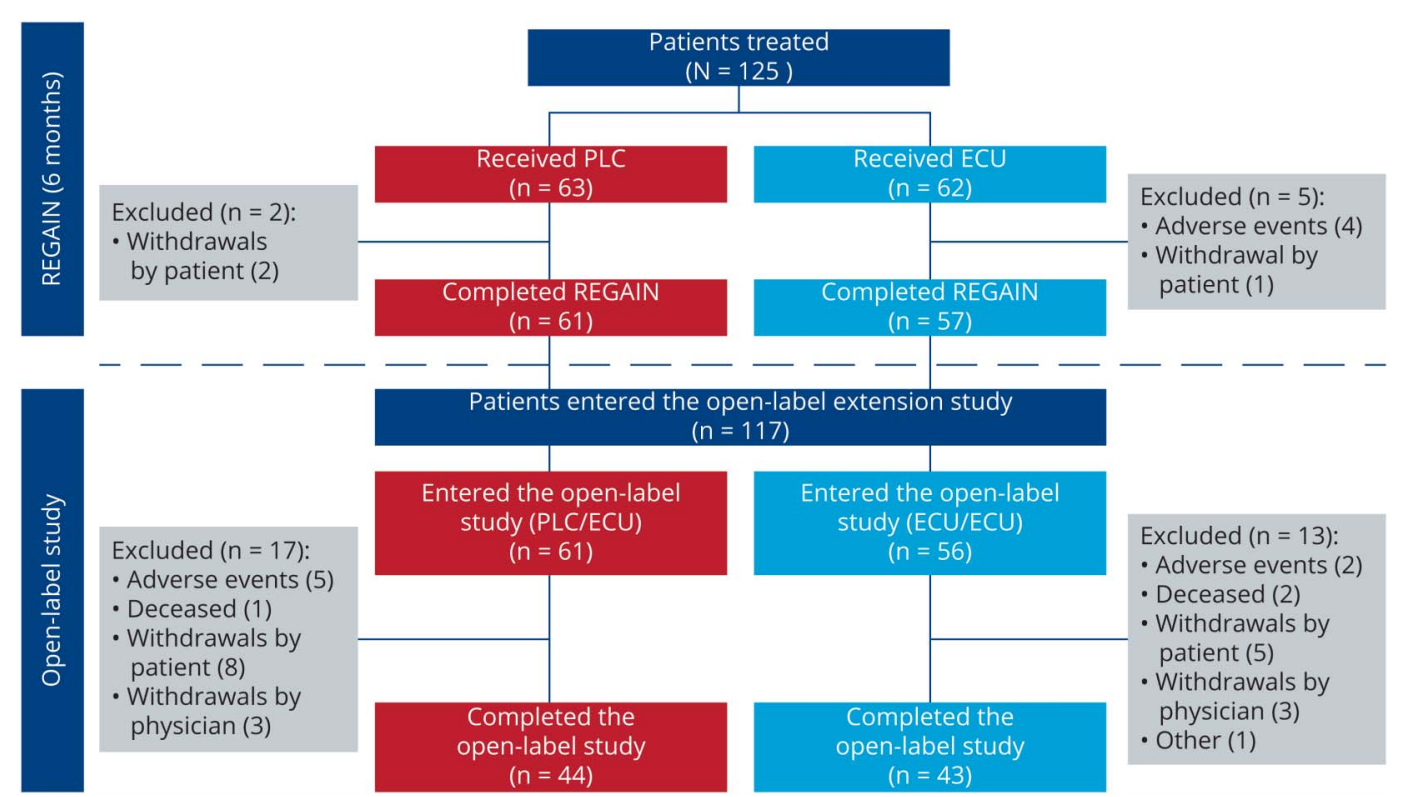

ECU = eculizumab; PLC = placebo. Figure reproduced with permission (creativecommons.org/licenses/by/4.0/) from Vissing et al. ${ }^{13}$

All statistical analyses were performed using SAS software version 9.4 (SAS Institute, Cary, NC).

\section{Classification of Evidence}

The primary research question of this analysis of data from the 6-month, phase 3, randomized, placebo-controlled REGAIN study and its open-label extension was whether adults with AChR+ refractory gMG could achieve an MGFA postintervention status of $\mathrm{MM}$ with eculizumab therapy.

This study provides Class II evidence that, in this previously difficult-to-treat patient population, after 26 weeks of treatment during REGAIN, a greater proportion treated with eculizumab than placebo achieved an MGFA postintervention status of MM (25.0\% vs $13.3 \%$; common OR 2.3; 95\% CI 1.1-4.5). After 130 weeks of eculizumab therapy, most patients (57.3\%) achieved MM status.

\section{Data Availability}

Alexion will consider requests for disclosure of clinical study participant-level data provided that participant privacy is assured through methods like data de-identification, pseudonymization, or anonymization (as required by applicable law), and if such disclosure was included in the relevant study informed consent form or similar documentation. Qualified academic investigators may request participant-level clinical data and supporting documents (statistical analysis plan and protocol) pertaining to Alexion-sponsored studies. Further details regarding data availability and instructions for requesting information are available in the Alexion Clinical Trials Disclosure and Transparency Policy at alexion.com/ research-development. The data request form is available at alexion.com/contact-alexion/medical-information.

\section{Results}

\section{Patient Demographics and Characteristics}

A total of 117 patients who completed REGAIN continued into the open-label study (eculizumab/eculizumab: 56; placebo/eculizumab: 61; figure 2) and were included in the efficacy and safety analysis. Patient demographics and characteristics, published previously, were similar for the eculizumab/eculizumab and placebo/eculizumab groups, with the exception that there was a greater proportion of Asian patients in the placebo/eculizumab group. ${ }^{9}$

The open-label extension study was completed with a final database lock in January 2019. At study completion, patients had participated in the study for different periods of time. A total of 87 patients completed the study (eculizumab/ eculizumab: 43; placebo/eculizumab: 44; figure 2). Of these, 71 patients (eculizumab/eculizumab: 35; placebo/ eculizumab: 36) had received open-label eculizumab for at least 130 weeks by the end of the study.

\section{MGFA Post-intervention Status During REGAIN and the Open-Label Study}

During REGAIN, at all time points assessed, a higher proportion of patients who received eculizumab than of those who were given placebo achieved improved status (table 1 and figure 3 ). At week $4,54.5 \%$ of eculizumab-treated patients $(30 / 55)$ achieved a status of improved compared with $24.6 \%$ 
Table 1 Change in Myasthenia Gravis Foundation of America Post-intervention Status From REGAIN (Safety and Efficacy of Eculizumab in Anti-acetylcholine Receptor-Positive Refractory Generalized Myasthenia Gravis) Baseline During REGAIN and Its Open-Label Extension by Treatment Group

\begin{tabular}{|c|c|c|c|c|c|c|c|c|c|}
\hline \multirow[b]{2}{*}{ Study } & \multirow[b]{2}{*}{ Visit $^{a}$} & \multicolumn{4}{|c|}{ Placebo/eculizumab $(n=61)$} & \multicolumn{4}{|c|}{ Eculizumab/eculizumab $(n=56)$} \\
\hline & & $\begin{array}{l}\text { Improved } \\
\mathrm{n} / \mathrm{N}^{\mathrm{b}}(\%) \\
{[95 \% \mathrm{Cl}]}\end{array}$ & $\begin{array}{l}\mathrm{MM} \\
\mathrm{n} / \mathrm{N}^{\mathrm{b}}(\%) \\
{[95 \% \mathrm{Cl}]}\end{array}$ & $\begin{array}{l}\text { Unchanged } \\
\text { n/N } \mathrm{N}^{\mathrm{b}}(\%) \\
{[95 \% \mathrm{Cl}]}\end{array}$ & $\begin{array}{l}\text { Worse } \\
\text { n/N } \mathrm{N}^{\mathrm{b}}(\%) \\
{[95 \% \mathrm{Cl}]}\end{array}$ & $\begin{array}{l}\text { Improved } \\
\text { n/N } \mathrm{N}^{\mathrm{b}}(\%) \\
{[95 \% \mathrm{Cl}]}\end{array}$ & $\begin{array}{l}\mathrm{MM} \\
\mathrm{n} / \mathrm{N}^{\mathrm{b}}(\%) \\
{[95 \% \mathrm{Cl}]}\end{array}$ & $\begin{array}{l}\text { Unchanged } \\
\text { n/N } \mathrm{N}^{\mathrm{b}}(\%) \\
{[95 \% \mathrm{Cl}]}\end{array}$ & $\begin{array}{l}\text { Worse } \\
n / N^{b}(\%) \\
{[95 \% \mathrm{Cl}]}\end{array}$ \\
\hline \multirow[t]{3}{*}{ REGAIN } & Week 4 & $\begin{array}{l}15 / 61(24.6) \\
{[14.5-37.3]}\end{array}$ & $\begin{array}{l}5 / 61(8.2) \\
{[2.7-18.1]}\end{array}$ & $\begin{array}{l}41 / 61(67.2) \\
{[54.0-78.7]}\end{array}$ & $\begin{array}{l}5 / 61(8.2) \\
{[2.7-18.1]}\end{array}$ & $\begin{array}{l}30 / 55(54.5) \\
{[40.6-68.0]}\end{array}$ & $\begin{array}{l}10 / 55(18.2) \\
{[9.1-30.9]}\end{array}$ & $\begin{array}{l}25 / 55(45.5) \\
{[32.0-59.4]}\end{array}$ & $\begin{array}{l}0 / 55(0.0) \\
{[0.0-6.5]}\end{array}$ \\
\hline & Week 12 & $\begin{array}{l}22 / 61(36.1) \\
{[24.2-49.4]}\end{array}$ & $\begin{array}{l}7 / 61(11.5) \\
{[4.7-22.2]}\end{array}$ & $\begin{array}{l}35 / 61(57.4) \\
{[44.1-70.0]}\end{array}$ & $\begin{array}{l}4 / 61(6.6) \\
{[1.8-15.9]}\end{array}$ & $\begin{array}{l}28 / 53(52.8) \\
{[38.6-66.7]}\end{array}$ & $\begin{array}{l}11 / 53(20.8) \\
{[10.8-34.1]}\end{array}$ & $\begin{array}{l}24 / 53(45.3) \\
{[31.6-59.6]}\end{array}$ & $\begin{array}{l}1 / 53(1.9) \\
{[0.0-10.1]}\end{array}$ \\
\hline & Week 26 & $\begin{array}{l}25 / 60(41.7) \\
{[29.1-55.1]}\end{array}$ & $\begin{array}{l}8 / 60(13.3) \\
{[5.9-24.6]}\end{array}$ & $\begin{array}{l}30 / 60(50.0) \\
{[36.8-63.2]}\end{array}$ & $\begin{array}{l}5 / 60(8.3) \\
{[2.8-18.4]}\end{array}$ & $\begin{array}{l}34 / 56(60.7) \\
{[46.8-73.5]}\end{array}$ & $\begin{array}{l}14 / 56(25.0) \\
{[14.4-38.4]}\end{array}$ & $\begin{array}{l}21 / 56(37.5) \\
{[24.9-51.5]}\end{array}$ & $\begin{array}{l}1 / 56(1.8) \\
{[0.0-9.6]}\end{array}$ \\
\hline \multirow{7}{*}{$\begin{array}{l}\text { Open- } \\
\text { label } \\
\text { study }\end{array}$} & Week 26 & $\begin{array}{l}40 / 56(71.4) \\
{[57.8-82.7]}\end{array}$ & $\begin{array}{l}27 / 56(48.2) \\
{[34.7-62.0]}\end{array}$ & $\begin{array}{l}15 / 56(26.8) \\
{[15.8-40.3]}\end{array}$ & $\begin{array}{l}1 / 56(1.8) \\
{[0.0-9.6]}\end{array}$ & $\begin{array}{l}36 / 48(75.0) \\
{[60.4-86.4]}\end{array}$ & $\begin{array}{l}22 / 48(45.8) \\
{[31.4-60.8]}\end{array}$ & $\begin{array}{l}12 / 48(25.0) \\
{[13.6-39.6]}\end{array}$ & $\begin{array}{l}0 / 48(0.0) \\
{[0.0-7.4]}\end{array}$ \\
\hline & Week 40 & $\begin{array}{l}46 / 54(85.2) \\
{[72.9-93.4]}\end{array}$ & $\begin{array}{l}34 / 54(63.0) \\
{[48.7-75.7]}\end{array}$ & $\begin{array}{l}7 / 54(13.0) \\
{[5.4-24.9]}\end{array}$ & $\begin{array}{l}1 / 54(1.9) \\
{[0.0-9.9]}\end{array}$ & $\begin{array}{l}37 / 49(75.5) \\
{[61.1-86.7]}\end{array}$ & $\begin{array}{l}21 / 49(42.9) \\
{[28.8-57.8]}\end{array}$ & $\begin{array}{l}10 / 49(20.4) \\
{[10.2-34.3]}\end{array}$ & $\begin{array}{l}2 / 49(4.1) \\
{[0.5-14.0]}\end{array}$ \\
\hline & Week 52 & $\begin{array}{l}44 / 54(81.5) \\
{[68.6-90.7]}\end{array}$ & $\begin{array}{l}31 / 54(57.4) \\
{[43.2-70.8]}\end{array}$ & $\begin{array}{l}10 / 54(18.5) \\
{[9.3-31.4]}\end{array}$ & $\begin{array}{l}0 / 54(0.0) \\
{[0.0-6.6]}\end{array}$ & $\begin{array}{l}41 / 48(85.4) \\
{[72.2-93.9]}\end{array}$ & $\begin{array}{l}22 / 48(45.8) \\
{[31.4-60.8]}\end{array}$ & $\begin{array}{l}6 / 48(12.5) \\
{[4.7-25.2]}\end{array}$ & $\begin{array}{l}1 / 48(2.1) \\
{[0.1-11.1]}\end{array}$ \\
\hline & Week 78 & $\begin{array}{l}42 / 48(87.5) \\
{[74.8-95.3]}\end{array}$ & $\begin{array}{l}29 / 48(60.4) \\
{[45.3-74.2]}\end{array}$ & $\begin{array}{l}5 / 48(10.4) \\
{[3.5-22.7]}\end{array}$ & $\begin{array}{l}1 / 48(2.1) \\
{[0.1-11.1]}\end{array}$ & $\begin{array}{l}37 / 47(78.7) \\
{[64.3-89.3]}\end{array}$ & $\begin{array}{l}22 / 47(46.8) \\
{[32.1-61.9]}\end{array}$ & $\begin{array}{l}\text { 9/47 (19.1) } \\
{[9.1-33.3]}\end{array}$ & $\begin{array}{l}1 / 47(2.1) \\
{[0.1-11.3]}\end{array}$ \\
\hline & Week 104 & $\begin{array}{l}34 / 37(91.9) \\
{[78.1-98.3]}\end{array}$ & $\begin{array}{l}22 / 37(59.5) \\
{[42.1-75.2]}\end{array}$ & $\begin{array}{l}2 / 37(5.4) \\
{[0.7-18.2]}\end{array}$ & $\begin{array}{l}1 / 37(2.7) \\
{[0.1-14.2]}\end{array}$ & $\begin{array}{l}33 / 40(82.5) \\
{[67.2-92.7]}\end{array}$ & $\begin{array}{l}21 / 40(52.5) \\
{[36.1-68.5]}\end{array}$ & $\begin{array}{l}6 / 40(15.0) \\
{[5.7-29.8]}\end{array}$ & $\begin{array}{l}1 / 40(2.5) \\
{[0.1-13.2]}\end{array}$ \\
\hline & Week 130 & $\begin{array}{l}33 / 35(94.3) \\
{[80.8-99.3]}\end{array}$ & $\begin{array}{l}22 / 35(62.9) \\
{[44.9-78.5]}\end{array}$ & $\begin{array}{l}2 / 35(5.7) \\
{[0.7-19.2]}\end{array}$ & $\begin{array}{l}0 / 35(0.0) \\
{[0.0-10.0]}\end{array}$ & $\begin{array}{l}28 / 35(80.0) \\
{[63.1-91.6]}\end{array}$ & $\begin{array}{l}18 / 35(51.4) \\
{[34.0-68.6]}\end{array}$ & $\begin{array}{l}5 / 35(14.3) \\
{[4.8-30.3]}\end{array}$ & $\begin{array}{l}2 / 35(5.7) \\
{[0.7-19.2]}\end{array}$ \\
\hline & $\begin{array}{l}\text { Last } \\
\text { assessment }\end{array}$ & $\begin{array}{l}47 / 57(82.5) \\
{[70.1-91.3]}\end{array}$ & $\begin{array}{l}31 / 57(54.4) \\
{[40.7-67.6]}\end{array}$ & $\begin{array}{l}9 / 57(15.8) \\
{[7.5-27.9]}\end{array}$ & $\begin{array}{l}1 / 57(1.8) \\
{[0.0-9.4]}\end{array}$ & $\begin{array}{l}40 / 56(71.4) \\
{[57.8-82.7]}\end{array}$ & $\begin{array}{l}23 / 56(41.1) \\
{[28.1-55.0]}\end{array}$ & $\begin{array}{l}13 / 56(23.2) \\
{[13.0-36.4]}\end{array}$ & $\begin{array}{l}3 / 56(5.4) \\
{[1.1-14.9]}\end{array}$ \\
\hline
\end{tabular}

Abbreviations: $\mathrm{Cl}=$ confidence interval; $\mathrm{MM}=$ minimal manifestations.

a Weeks are numbered separately for REGAIN (0-26) and the open-label study (0-130).

${ }^{\mathrm{b}}$ At the time of study completion, patients had participated for different periods of time. The numbers of patients at each time point reflect this and also account for discontinuations and for patients who did not complete the assessment at the specified time point.

of placebo-treated patients (15/61). At week $26,60.7 \%$ of eculizumab-treated patients $(34 / 56)$ had achieved a status of improved, compared with $41.7 \%$ of placebo-treated patients $(25 / 60)$. One patient who received eculizumab had a status of worse at week 26 compared with 5 individuals who received placebo. By week 130 of the open-label study, most patients in both groups had achieved improved status: $80.0 \%$ of participants in the eculizumab/eculizumab group (28/35) and $94.3 \%$ of those in the placebo/eculizumab group (33/35; 1 patient did not complete the assessment). Of the 117 patients enrolled in the open-label extension study, 113 were assessed for MGFA post-intervention status at their last assessment: $71.4 \%$ of patients in the eculizumab/eculizumab group (40/ 56 ) and $82.5 \%$ of those in the placebo/eculizumab group (47/ 57) achieved improved status.

During REGAIN, the proportion of patients receiving eculizumab who achieved MM increased from $18.2 \%(10 / 55)$ at week 4 to $25.0 \%(14 / 56)$ at week 26 (table 1 and figure 3 ). MM status was achieved by a smaller proportion of the placebo group (8.2\% [5/61] at week 4 and $13.3 \%$ [8/60] at week 26) than of the eculizumab group. Eculizumab-treated patients were more likely to achieve a status of improved or MM at REGAIN week 26 than those given placebo (common OR 2.3; 95\% CI 1.1-4.5). By week 130 of the open-label study, the proportion of patients achieving MM had increased to $51.4 \%$ in the eculizumab/eculizumab group (18/35) and to $62.9 \%$ in the placebo/eculizumab group (22/35). At last assessment, MM was achieved by $41.1 \%$ of patients in the eculizumab/eculizumab group (23/56) and $54.4 \%$ of patients in the placebo/eculizumab group (31/57).

Patients in the eculizumab/eculizumab and placebo/ eculizumab groups received eculizumab for different periods of time during REGAIN and its open-label extension; of all patients who received eculizumab for 26 weeks (eculizumab/ eculizumab group to week 26 of REGAIN and placebo/ eculizumab group to week 26 of the open-label study), most $(66.1 \% ; 74 / 112)$ achieved improved status and over one-third (36.6\%; 41/112) achieved MM status (table 2). Almost onethird of participants $(32.1 \% ; 36 / 112)$ had a status of unchanged and 2 patients had a status of worse after 26 weeks' eculizumab therapy (table 2). The proportions of patients who achieved improved or MM status increased with 
Figure 3 Patients Who Achieved Myasthenia Gravis Foundation of America Post-intervention Status of Improved or Minimal Manifestations at REGAIN (Safety and Efficacy of Eculizumab in Anti-acetylcholine Receptor-Positive Refractory Generalized Myasthenia Gravis) Weeks 4, 12, and 26, and Open-Label Study Weeks 26, 52, 78, 104, and 130

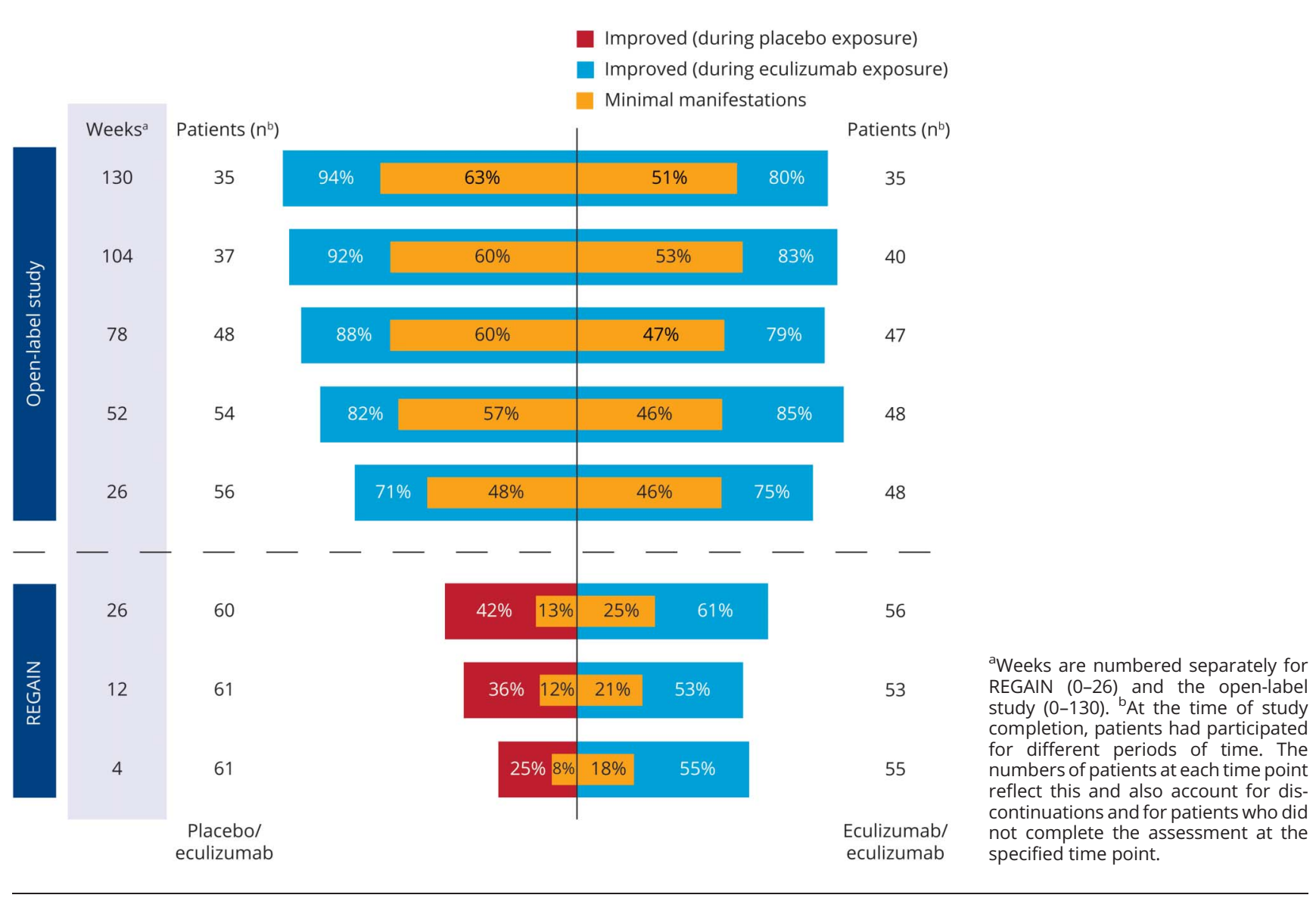

continued eculizumab treatment: $88.0 \%(66 / 75)$ of those who received eculizumab for 130 weeks achieved improved status and 57.3\% (43/75) achieved MM status (table 2). In addition, 2 patients achieved PR after 130 weeks of eculizumab therapy. At last assessment, $77.0 \%$ of patients (87/113) achieved improved status and 47.8\% (54/113) achieved MM status (table 2).

There were no differences in mean age ( 46.5 vs 47.4 years; difference $-0.9 ; 95 \% \mathrm{CI}-7.6$ to 5.8 ) or mean disease duration (9.3 vs

Table 2 Change in Myasthenia Gravis Foundation of America Post-intervention Status from REGAIN (Safety and Efficacy of Eculizumab in Anti-acetylcholine Receptor-Positive Refractory Generalized Myasthenia Gravis) Baseline by Eculizumab Treatment Duration

\begin{tabular}{lllll}
\hline Duration of eculizumab treatment, wk & Improved & MM & Unchanged & Worse \\
\hline $\mathbf{2 6}$ & $74 / 112(66.1)[56.5-74.7]$ & $41 / 112(36.6)[27.7-46.2]$ & $36 / 112(32.1)[23.6-41.6]$ & $2 / 112(1.8)[0.2-6.3]$ \\
\hline $\mathbf{5 2}$ & $80 / 102(78.4)[69.2-86.0]$ & $53 / 102(52.0)[41.8-62.0]$ & $22 / 102(21.6)[14.0-30.8]$ & $0 / 102(0.0)[0.0-3.6]$ \\
\hline $\mathbf{7 8}$ & $83 / 96(86.5)[78.0-92.6]$ & $51 / 96(53.1)[42.7-63.4]$ & $11 / 96(11.5)[5.9-19.6]$ & $2 / 96(2.1)[0.3-7.3]$ \\
\hline $\mathbf{1 0 4}$ & $71 / 84(84.5)[75.0-91.5]$ & $44 / 84(52.4)[41.2-63.4]$ & $11 / 84(13.1)[6.7-22.2]$ & $2 / 84(2.4)[0.3-8.3]$ \\
\hline $\mathbf{1 3 0}$ & $66 / 75(88.0)[78.4-94.4]$ & $43 / 75(57.3)[45.4-68.7]$ & $8 / 75(10.7)[4.7-19.9]$ & $1 / 75(1.3)[0.0-7.2]$ \\
\hline Last assessment & $87 / 113(77.0)[68.1-84.4]$ & $54 / 113(47.8)[38.3-57.4]$ & $22 / 113(19.5)[12.6-28.0]$ & $4 / 113(3.5)[1.0-8.8]$
\end{tabular}

Abbreviation: $\mathrm{MM}=$ minimal manifestations.

At the time of study completion, patients had participated for different periods of time. The numbers of patients listed for each treatment duration reflect this and also account for discontinuations and for patients who did not complete the assessment at the specified time point. Values are $\mathrm{n} / \mathrm{N}$ (\%) [95\% confidence interval]. 
Table 3 Changes in Mean Daily Immunosuppressive Therapy Doses in Patients Who First Achieved Minimal Manifestations (MM) Status During the Open-Label Study

\begin{tabular}{lllll}
\hline IST & $\begin{array}{l}\text { No. of patients using IST at open-label } \\
\text { baseline who first achieved MM during the } \\
\text { open-label study }\end{array}$ & $\begin{array}{l}\text { Mean (SD) daily dose } \\
\text { at open-label } \\
\text { baseline, mg }\end{array}$ & $\begin{array}{l}\text { Last reported mean (SD) daily } \\
\text { dose before first achieving } \\
\text { MM, mg }\end{array}$ & $\begin{array}{l}\text { Percent change in } \\
\text { mean (SD) daily } \\
\text { dose }\end{array}$ \\
\hline Corticosteroids & 47 & $17.0(11.85)$ & $12.9(10.29)$ & $-18.7(33.11)$ \\
\hline Azathioprine & 24 & $163.5(67.96)$ & $130.2(92.95)$ & $-26.0(40.77)$ \\
\hline $\begin{array}{l}\text { Mycophenolate } \\
\text { mofetil }\end{array}$ & 13 & $2,206.9(1,139.06)$ & $1,855.0(1,148.80)$ & $-16.0(30.14)$ \\
\hline
\end{tabular}

Abbreviation: IST = immunosuppressive therapy.

10.3 years; difference $-1.0 ; 95 \%$ CI -4.2 to 2.2 ) between eculizumab-treated patients who achieved MM status up to openlabel study week $130(\mathrm{n}=76)$ and those who did not $(\mathrm{n}=37)$. Among the 76 eculizumab-treated patients who achieved MM status up to open-label study week 130, 58 (76.3\%) were using corticosteroids, $29(38.2 \%)$ were using azathioprine, and 16 $(21.1 \%)$ were using mycophenolate mofetil at open-label baseline.

The mean daily doses of ISTs used by patients who first achieved MM status during the open-label study decreased between open-label baseline and last reported dose before first achieving MM status. In those using each IST at openlabel baseline, the mean daily doses of corticosteroids, azathioprine, and mycophenolate mofetil decreased by $18.7 \%$, $26.0 \%$, and $16.0 \%$, respectively (table 3 ).

\section{Safety}

Safety data have previously been published for REGAIN and the interim analysis of the open-label study. ${ }^{8,9}$ Across these 2 studies, the most common adverse events with eculizumab for patients included in this analysis were headache and nasopharyngitis, which were experienced by $44.4 \%$ and $38.5 \%$ of patients, respectively (table 4). Serious adverse events of worsening of MG and MG crisis occurred in $15.4 \%$ and $3.4 \%$ of patients, respectively. MG exacerbations were experienced by $29.1 \%$ of patients, and $25.6 \%$ used rescue therapy. During REGAIN and the open-label study, 11 patients discontinued because of an adverse event, and 3 deaths occurred, which were all considered likely to be related to comorbidities (figure 2). ${ }^{9}$ There were 16 patients who withdrew themselves from REGAIN or the open-label study, 6 patients who were withdrawn by their physician, and 1 patient who discontinued for "other" reasons; no further information was collected regarding the reasons for these discontinuations.

\section{Discussion}

This analysis found that patients with AChR+ refractory gMG treated with eculizumab experienced rapid improvements in their clinical condition based on MGFA post-intervention status. Over $50 \%$ of patients achieved a status of improved within 4 weeks of their first dose of eculizumab in REGAIN and one-third of these patients also achieved MM. By REGAIN week 26, significantly higher proportions of eculizumab-treated patients than placebo-treated patients achieved an MGFA post-intervention status of improved or MM.

Long-term eculizumab treatment was associated with further increases in the proportions of patients who achieved a status of improved or MM. After 130 weeks of eculizumab therapy, almost $90 \%$ of patients remaining in the study had attained a status of improved and nearly $60 \%$ had achieved MM. Notably, in patients who achieved MM status during the open-label study, mean daily doses of concomitant ISTs were reduced before they first achieved MM. These findings suggest that for some patients with AChR+ refractory gMG, long-term treatment with eculizumab is beneficial for optimal disease control. Furthermore, 2 patients achieved PR after 130 weeks of eculizumab treatment, reflecting long-term maintenance of symptom relief.

The long-term safety profile of eculizumab was consistent with its known profile from over 10 years of clinical use in other indications, ${ }^{10-12}$ and no new safety signals were observed during the open-label study.

The main limitation of this analysis is the open-label design of the extension study, which could yield unconscious bias towards reporting of positive outcomes with eculizumab. Because over $90 \%$ of patients who enrolled in REGAIN continued into the open-label study, selection bias in the open-label study population is unlikely.

The results of this analysis confirm the rapid and sustained clinical response to eculizumab that was observed during REGAIN and the open-label study. Over $50 \%$ of patients who were considered to have refractory disease achieved the consensus treatment goal of MM or better after 1 year of eculizumab treatment. These findings further support the long-term effectiveness of eculizumab for use in patients with AChR+ refractory gMG.

\section{Acknowledgment}

The authors thank REGAIN and extension study participants and their families, investigators, and collaborators; Sivani Paskaradevan (Alexion Pharmaceuticals) for critical review of 
Table 4 Safety Outcomes for the Study Population During REGAIN (Safety and Efficacy of Eculizumab in Anti-acetylcholine Receptor-Positive Refractory Generalized Myasthenia Gravis) and the Open-Label Study

\begin{tabular}{|c|c|c|c|c|c|c|}
\hline \multirow[b]{2}{*}{ Outcome } & \multicolumn{2}{|c|}{$\begin{array}{l}\text { REGAIN placebo }(n=61 \\
\left.30.9 \mathrm{PY}^{\mathrm{a}}\right)\end{array}$} & \multicolumn{2}{|c|}{$\begin{array}{l}\text { REGAIN eculizumab }(n=56, \\
\left.28.2 P^{\mathrm{a}}\right)\end{array}$} & \multicolumn{2}{|c|}{$\begin{array}{l}\text { REGAIN and open-label study } \\
\text { eculizumab }(\mathrm{N}=117 \\
\left.305.1 \mathrm{PY}^{\mathrm{a}}\right)\end{array}$} \\
\hline & $\begin{array}{l}\text { Patients } \\
\text { with event, } \\
\mathrm{n}(\%)\end{array}$ & $\begin{array}{l}\text { Event rate } \\
\text { (events/100 } \\
\text { PYa) }\end{array}$ & $\begin{array}{l}\text { Patients } \\
\text { with event, } \\
\text { n (\%) }\end{array}$ & $\begin{array}{l}\text { Event rate } \\
\text { (events/100 } \\
\text { PYa) }\end{array}$ & $\begin{array}{l}\text { Patients } \\
\text { with event, } \\
\mathrm{n}(\%)\end{array}$ & $\begin{array}{l}\text { Event rate } \\
\text { (events/100 } \\
\text { PYa) }^{\text {Py }}\end{array}$ \\
\hline Exacerbation & $13(21.3)$ & 77.7 & $4(7.1)$ & 35.5 & $34(29.1)$ & 23.9 \\
\hline Rescue therapy use & $10(16.4)$ & 68.0 & $4(7.1)$ & 35.5 & $30(25.6)$ & 22.0 \\
\hline \multicolumn{7}{|c|}{$\begin{array}{l}\text { Most common adverse events }{ }^{b, c}(>15 \% \text { of all } \\
\text { patients) }\end{array}$} \\
\hline Headache & $12(19.7)$ & 90.6 & $10(17.9)$ & 88.7 & $52(44.4)$ & 32.8 \\
\hline Nasopharyngitis & $10(16.4)$ & 42.1 & $9(16.1)$ & 46.1 & $45(38.5)$ & 32.1 \\
\hline Diarrhea & $8(13.1)$ & 29.1 & $8(14.3)$ & 35.5 & $33(28.2)$ & 17.4 \\
\hline Upper respiratory tract infection & $12(19.7)$ & 45.3 & $9(16.1)$ & 46.1 & $31(26.5)$ & 25.2 \\
\hline Nausea & $9(14.8)$ & 84.1 & $7(12.5)$ & 35.5 & $27(23.1)$ & 12.1 \\
\hline Myasthenia gravis $^{d}$ & $9(14.8)$ & 58.3 & $4(7.1)$ & 14.2 & $30(25.6)$ & 17.4 \\
\hline Arthralgia & $5(8.2)$ & 29.1 & $1(1.8)$ & 3.5 & $24(20.5)$ & 10.5 \\
\hline Pain in extremity & $2(3.3)$ & 6.5 & $4(7.1)$ & 14.2 & $20(17.1)$ & 8.5 \\
\hline Urinary tract infection & $5(8.2)$ & 22.7 & $3(5.4)$ & 14.2 & $20(17.1)$ & 12.5 \\
\hline \multicolumn{7}{|c|}{$\begin{array}{l}\text { Most common myasthenia gravis- and } \\
\text { infection-related serious adverse events }{ }^{b, c}(\geq 2 \\
\text { patients) }\end{array}$} \\
\hline Myasthenia gravis $^{d}$ & $6(9.8)$ & 45.3 & $3(5.4)$ & 10.6 & $18(15.4)$ & 10.5 \\
\hline Pyrexia & $0(0.0)$ & 0.0 & $2(3.6)$ & 7.1 & $5(4.3)$ & 1.6 \\
\hline Myasthenia gravis crisis & $0(0.0)$ & 0.0 & $0(0.0)$ & 0.0 & $4(3.4)$ & 1.3 \\
\hline Acute respiratory failure & $0(0.0)$ & 0.0 & $0(0.0)$ & 0.0 & $3(2.6)$ & 1.0 \\
\hline Gastroenteritis & $1(1.6)$ & 9.7 & $0(0.0)$ & 0.0 & $3(2.6)$ & 1.0 \\
\hline Pneumonia & $0(0.0)$ & 0.0 & $0(0.0)$ & 0.0 & $4(3.4)$ & 1.6 \\
\hline Sepsis & $0(0.0)$ & 0.0 & $0(0.0)$ & 0.0 & $3(2.6)$ & 1.0 \\
\hline Bronchitis & $0(0.0)$ & 0.0 & $0(0.0)$ & 0.0 & $2(1.7)$ & 1.0 \\
\hline Urinary tract infection & $0(0.0)$ & 0.0 & $0(0.0)$ & 0.0 & $2(1.7)$ & 1.0 \\
\hline Influenza & $0(0.0)$ & 0.0 & $0(0.0)$ & 0.0 & $2(1.7)$ & 0.7 \\
\hline Upper respiratory tract infection & $2(3.3)$ & 6.5 & $0(0.0)$ & 0.0 & $2(1.7)$ & 0.7 \\
\hline Pneumonia aspiration & $0(0.0)$ & 0.0 & $0(0.0)$ & 0.0 & $2(1.7)$ & 0.7 \\
\hline Localized infection & $0(0.0)$ & 0.0 & $0(0.0)$ & 0.0 & $2(1.7)$ & 0.7 \\
\hline
\end{tabular}

Abbreviation: PY = patient-year

${ }^{\text {a }} \mathrm{PY}$ is the sum of all years for all patients and the observed event rate is the number of events per PY multiplied by 100.

${ }^{b}$ Medical Dictionary for Regulatory Activities preferred term.

"If a patient had more than 1 adverse event for a particular preferred term, that patient is counted only once for that preferred term.

${ }^{\mathrm{d}}$ Worsening (increased frequency and/or intensity) of a preexisting condition, including myasthenia gravis, is considered to be an adverse event.

the manuscript; and Cindy Lane (formerly of Alexion Pharmaceuticals) for clinical study oversight.

\section{Study Funding}

This work was funded by Alexion Pharmaceuticals.

\section{Disclosure}

R. Mantegazza received funding for research and congress participation from Bayer, BioMarin, Sanofi-Genzyme, and Teva, and participated in scientific advisory boards for Alexion Pharmaceuticals, argenx, and BioMarin. G.I. Wolfe reports 
research support from Alexion Pharmaceuticals, CSL Behring, and Ra Pharmaceuticals, and advisory board compensation from argenx and Syntimmune. S. Muppidi was a consultant for Alexion Pharmaceuticals. H. Wiendl received honoraria for participation in scientific advisory boards and consultation for Biogen, Evgen, MedDay Pharmaceuticals, Merck Serono, Novartis, Roche Pharma $A G$, and Sanofi-Genzyme, and speaker honoraria and travel support from Alexion Pharmaceuticals, Biogen, Cognomed, F. Hoffmann-La Roche Ltd, Gemeinnützige Hertie-Stiftung, Merck Serono, Novartis, Roche Pharma AG, Sanofi-Genzyme, Teva, and WebMD Global. He has been a paid consultant for AbbVie, Actelion, Biogen, IGES, Novartis, Roche Pharma AG, Sanofi-Genzyme, and the Swiss Multiple Sclerosis Society. His research is funded by the German Ministry for Education and Research (BMBF), Deutsche Forschungsgesellschaft (DFG), Else Kröner-Fresenius Foundation, Hertie Foundation, NRW Ministry of Education and Research, Interdisciplinary Center for Clinical Studies (IZKF) Müenster and RE Children's Foundation, Biogen GmbH, GlaxoSmithKline GmbH, Roche Pharma AG, and SanofiGenzyme. K.P. Fujita was employed by and owns stock in Alexion Pharmaceuticals and is employed by Alnylam Pharmaceuticals. F.L. O'Brien is employed by and owns stock in Alexion Pharmaceuticals. H.D.E. Booth is employed by Oxford PharmaGenesis, which received funding from Alexion Pharmaceuticals for medical writing support. J.F. Howard received research support from argenx BVBA, Alexion Pharmaceuticals, the Muscular Dystrophy Association, Ra Pharmaceuticals, the Centers for Disease Control and Prevention (Atlanta, GA), and the NIH (including the National Institute of Neurologic Disorders and Stroke and the National Institute of Arthritis and Musculoskeletal and Skin Diseases); consulting fees from Alexion Pharmaceuticals; honoraria from Alexion Pharmaceuticals; and nonfinancial support from Alexion Pharmaceuticals, argenx BVBA, Ra Pharmaceuticals, and Toleranzia. Go to Neurology.org/ $\mathrm{N}$ for full disclosures.

\section{Publication History}

Received by Neurology November 6, 2019. Accepted in final form September 11, 2020.

\section{Appendix 1 Authors}

\begin{tabular}{lll}
\hline Name & Location & Contribution \\
\hline $\begin{array}{l}\text { Renato } \\
\text { Mantegazza, } \\
\text { MD }\end{array}$ & $\begin{array}{l}\text { Milan, } \\
\text { Italy }\end{array}$ & $\begin{array}{l}\text { Major role in data acquisition, data } \\
\text { analysis/interpretation, drafting/revising } \\
\text { the manuscript for intellectual content, } \\
\text { final approval of the manuscript }\end{array}$ \\
\hline $\begin{array}{l}\text { Gil I. Wolfe, } \\
\text { MD }\end{array}$ & Buffalo, & $\begin{array}{l}\text { Major role in data acquisition, data } \\
\text { analysis/interpretation, drafting/revising } \\
\text { the manuscript for intellectual content, } \\
\text { final approval of the manuscript }\end{array}$ \\
& &
\end{tabular}

Appendix 1 (continued)

\begin{tabular}{|c|c|c|}
\hline Name & Location & Contribution \\
\hline $\begin{array}{l}\text { Srikanth } \\
\text { Muppidi, MD }\end{array}$ & $\begin{array}{l}\text { Stanford, } \\
\text { CA }\end{array}$ & $\begin{array}{l}\text { Major role in data acquisition, data } \\
\text { analysis/interpretation, drafting/revising } \\
\text { the manuscript for intellectual content, } \\
\text { final approval of the manuscript }\end{array}$ \\
\hline $\begin{array}{l}\text { Heinz Wiendl, } \\
\text { MD }\end{array}$ & $\begin{array}{l}\text { Münster, } \\
\text { Germany }\end{array}$ & $\begin{array}{l}\text { Major role in data acquisition, data } \\
\text { analysis/interpretation, drafting/revising } \\
\text { the manuscript for intellectual content, } \\
\text { final approval of the manuscript }\end{array}$ \\
\hline $\begin{array}{l}\text { Kenji P. Fujita, } \\
\text { MD }\end{array}$ & $\begin{array}{l}\text { Boston, } \\
\text { MA }\end{array}$ & $\begin{array}{l}\text { Study design/conceptualization, major } \\
\text { role in data acquisition, data analysis/ } \\
\text { interpretation, drafting/revising the } \\
\text { manuscript for intellectual content, final } \\
\text { approval of the manuscript }\end{array}$ \\
\hline $\begin{array}{l}\text { Fanny L. } \\
\text { O'Brien, PhD }\end{array}$ & $\begin{array}{l}\text { Boston, } \\
\text { MA }\end{array}$ & $\begin{array}{l}\text { Study design/conceptualization, major } \\
\text { role in data acquisition, data analysis/ } \\
\text { interpretation, drafting/revising the } \\
\text { manuscript for intellectual content, final } \\
\text { approval of the manuscript }\end{array}$ \\
\hline $\begin{array}{l}\text { Heather D.E. } \\
\text { Booth, DPhil }\end{array}$ & $\begin{array}{l}\text { Oxford, } \\
\text { UK }\end{array}$ & $\begin{array}{l}\text { Drafting or revising the manuscript for } \\
\text { intellectual content, final approval of the } \\
\text { manuscript }\end{array}$ \\
\hline $\begin{array}{l}\text { James F. } \\
\text { Howard, Jr, } \\
\text { MD }\end{array}$ & $\begin{array}{l}\text { Chapel } \\
\text { Hill, NC }\end{array}$ & $\begin{array}{l}\text { Study design/conceptualization, major } \\
\text { role in data acquisition, data analysis/ } \\
\text { interpretation, drafting/revising the } \\
\text { manuscript for intellectual content, final } \\
\text { approval of the manuscript }\end{array}$ \\
\hline
\end{tabular}

Appendix 2 Coinvestigators

Coinvestigators are listed at links.Iww.com/WNL/B275

\section{References}

1. Suh J, Goldstein JM, Nowak RJ. Clinical characteristics of refractory myasthenia gravis patients. Yale J Biol Med 2013;86:255-260.

2. Silvestri NJ, Wolfe GI. Treatment-refractory myasthenia gravis. J Clin Neuromuscul Dis 2014;15:167-178.

3. Sanders DB, Wolfe GI, Benatar M, et al. International consensus guidance for management of myasthenia gravis: executive summary. Neurology 2016;87:419-425.

4. Engel-Nitz NM, Boscoe A, Wolbeck R, Johnson J, Silvestri NJ. Burden of illness in patients with treatment refractory myasthenia gravis. Muscle Nerve 2018;58:99-105.

5. Murai $\mathrm{H}$. Japanese clinical guidelines for myasthenia gravis: putting into practice. Clin Exp Neuroimmunol 2015;6:21-31.

6. Jaretzki A III, Barohn RJ, Ernstoff RM, et al. Myasthenia gravis: recommendations for clinical research standards: Task Force of the Medical Scientific Advisory Board of the Myasthenia Gravis Foundation of America. Ann Thorac Surg 2000;70:327-334.

7. Rother RP, Rollins SA, Mojcik CF, Brodsky RA, Bell L. Discovery and development of the complement inhibitor eculizumab for the treatment of paroxysmal nocturnal hemoglobinuria. Nat Biotechnol 2007;25:1256-1264.

8. Howard JF Jr, Utsugisawa K, Benatar M, et al. Safety and efficacy of eculizumab in anti-acetylcholine receptor antibody-positive refractory generalised myasthenia gravis (REGAIN): a phase 3, randomised, double-blind, placebo-controlled, multicentre study. Lancet Neurol 2017;16:976-986.

9. Muppidi S, Utsugisawa K, Benatar M, et al. Long-term safety and efficacy of eculizumab in generalized myasthenia gravis. Muscle Nerve 2019;60:14-24.

10. Legendre CM, Licht $\mathrm{C}$, Muus $\mathrm{P}$, et al. Terminal complement inhibitor eculizumab in atypical hemolytic-uremic syndrome. N Engl J Med 2013;368:2169-2181.

11. Licht C, Greenbaum LA, Muus P, et al. Efficacy and safety of eculizumab in atypical hemolytic uremic syndrome from 2-year extensions of phase 2 studies. Kidney Int 2015;87:1061-1073.

12. Hillmen P, Young NS, Schubert J, et al. The complement inhibitor eculizumab in paroxysmal nocturnal hemoglobinuria. N Engl J Med 2006;355:1233-1243.

13. Vissing J, Jacob S, Fujita KP, et al. "Minimal symptom expression" in patients with acetylcholine receptor antibody-positive refractory generalized myasthenia gravis treated with eculizumab. J Neurol 2020;267:1991-2001. 


\section{Neurology}

\section{Post-intervention Status in Patients With Refractory Myasthenia Gravis Treated With Eculizumab During REGAIN and Its Open-Label Extension}

Renato Mantegazza, Gil I. Wolfe, Srikanth Muppidi, et al.

Neurology 2021;96;e610-e618 Published Online before print November 23, 2020

DOI 10.1212/WNL.0000000000011207

This information is current as of November 23, 2020

Updated Information \& Services

References

Subspecialty Collections

Permissions \& Licensing

Reprints including high resolution figures, can be found at: http://n.neurology.org/content/96/4/e610.full

This article cites 13 articles, 0 of which you can access for free at: http://n.neurology.org/content/96/4/e610.full\#ref-list-1

This article, along with others on similar topics, appears in the following collection(s):

All Clinical trials

http://n.neurology.org/cgi/collection/all_clinical_trials

Autoimmune diseases

http://n.neurology.org/cgi/collection/autoimmune_diseases

Class II

http://n.neurology.org/cgi/collection/class_ii

Myasthenia

http://n.neurology.org/cgi/collection/myasthenia

Information about reproducing this article in parts (figures,tables) or in its entirety can be found online at:

http://www.neurology.org/about/about_the_journal\#permissions

Information about ordering reprints can be found online:

http://n.neurology.org/subscribers/advertise

Neurology ${ }^{\circledR}$ is the official journal of the American Academy of Neurology. Published continuously since 1951, it is now a weekly with 48 issues per year. Copyright Copyright ( 2020 The Author(s). Published by Wolters Kluwer Health, Inc. on behalf of the American Academy of Neurology.. All rights reserved. Print ISSN: 0028-3878. Online ISSN: 1526-632X.

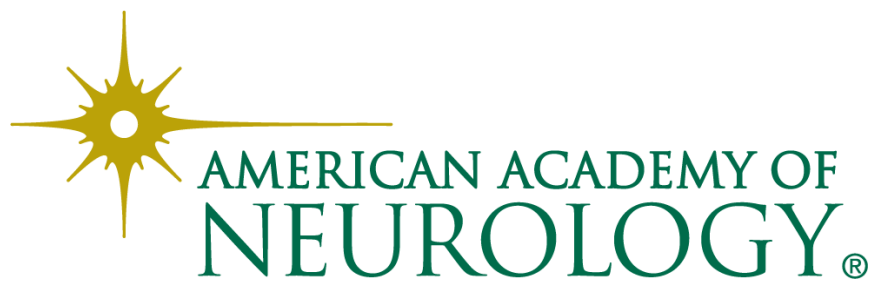

